\title{
The effect of water stress on seed germination of three terrestrial bromeliads from restinga ${ }^{1}$
}

\author{
ANDRÉ MANTOVANI ${ }^{2,4}$ and RICARDO R. IGLESIAS ${ }^{3}$
}

(received: February 14, 2008; accepted: February 03, 2010)

\begin{abstract}
The effect of water stress on seed germination of three terrestrial bromeliads from restinga). Bromeliad seedlings are rarely found on sandy coastal plains (restinga), limited, probably, by stressful conditions and/or specific abiotic requirements for germination. The effect of water stress on rate, time, synchronicity and spreading of germination was evaluated here for three terrestrial bromeliads from the restinga of Maricá using osmotic solutions of polyethyleneglicol 6000 (PEG 6000), from 0.0 to $-0.26 \mathrm{MPa}$ for 30 days. Water stress induced by PEG lowered rate and increased time and synchronicity values, besides the number of daily events of bromeliad seed germination, under water potentials between 0.00 to $-0.14 \mathrm{MPa}$. No seeds germinated under water potentials lower than $-0.14 \mathrm{MPa}$. These results reinforce a constant and/or high moisture requirement for bromeliad seeds to germinate. We conclude that bromeliads are not able to act as pioneer plants through germination outside the vegetation islands of the restinga of Maricá, due to the inability of seeds to germinate under lower water potential.
\end{abstract}

Keywords - Bromeliaceae, PEG, sandy plains, seed

RESUMO (Efeito do estresse hídrico sobre a germinação de sementes de três espécies de bromélias terrestres de restinga). Plântulas de bromélias são raramente encontradas em restingas, provavelmente limitadas pelas condições abióticas estressantes e/ou requerimentos abióticos específicos para germinação de sementes. Neste trabalho o efeito do estresse hídrico sobre a taxa, tempo, sincronicidade e distribuição dos eventos diários de germinação são avaliados para três bromélias terrestres da restinga de Maricá com uso de soluções osmóticas de polietilenoglicol 6000 (PEG 6000) de 0.0 MPa até -0,26 MPa durante 30 dias. O estresse hídrico induzido por PEG reduziu a taxa e elevou o tempo, os índices de sincronicidade e o número de eventos diários com novas germinações de sementes das bromélias estudadas, para potenciais hídricos entre 0.00 e -0.14 MPa. Não ocorreu germinação sob potenciais hídricos menores que -0,14 MPa. Estes resultados reforçam a hipótese de um requerimento por fornecimento hídrico constante e/ou elevado para germinação de bromélias em condições de campo. Concluímos que as bromélias terrestres não agem como plantas pioneiras através de germinação de sementes nas áreas entre moitas da restinga de Barra de Marica, devido à incapacidade das sementes de germinar em condições de baixo potencial de água.

Palavras-chave - Bromeliaceae, PEG, restingas, sementes

\section{Introduction}

The most characteristic physiognomy of restinga is a patchy habitat represented by vegetation islands surrounded by bare sand. Environmental conditions outside these islands are hostile to plant establishment, making seed germination, seedling establishment and the consequent vegetation island initiation difficult

1. Part of the $\mathrm{PhD}$ thesis from the first author developed at the Programa de Pós-Graduação em Ecologia, Universidade Federal do Rio de Janeiro, Rio de Janeiro, RJ, Brazil.

2. Instituto de Pesquisas Jardim Botânico do Rio de Janeiro, Rua Pacheco Leão 915, Jardim Botânico, 22460-030 Rio de Janeiro, RJ, Brazil.

3. Universidade Federal do Rio de Janeiro, Instituto de Biologia, Departamento de Ecologia, Laboratório de Ecologia de Comunidades, Bloco A, sala A2 102, CCS, Cidade Universitária, Caixa Postal 68020, 21944.590 Rio de Janeiro, RJ, Brazil.
(Mantovani \& Iglesias 2008). Under these conditions nurse plants would be an important trigger to plant succession on restingas.

Small vegetation islands are commonly occupied by Allagoptera arenaria (Gomes) Kuntze (Palmae), the woody species Clusia hilariana Schtdl. (Clusiaceae) and bromeliads as Aechmea nudicaulis (L.) Griseb, Neoregelia cruenta Graham Smith and Vriesea neoglutinosa Mez (Silva \& Oliveira 1989). Although terrestrial bromeliads produce fruits and viable seeds, seedlings are not commonly found germinating on restinga soil (Mantovani \& Iglesias 2001).

The apparent absence of bromeliad seedlings suggests that limiting factors are acting during seed germination or seedling establishment phases (Zotz \& Vollrath 2002). Available data indicate that seed germination of terrestrial bromeliads is limited in restinga ecosystem by high temperatures (Pinheiro 
\& Borghetti 2003, Vieira et al. 2007) or water stress (Pompelli et al. 2006).

One methodological approach commonly used to detect water stress as a limiting factor for seed germination is the application of polyethyleneglicol (PEG) as an osmotic medium (Michael \& Kaufman 1972). There are few data about the effect of osmotic stress on bromeliad seed germination (Benzing 2000). In this paper we furnish data about time, rate and synchronicity of seed germination of three terrestrial bromeliads under water stress in order to better understand the ecological dynamics of nurse plants in restinga ecosystem.

\section{Material and methods}

This study was carried out at the restinga of Maricá, RJ, southeastern Brazil (22 $\left.53^{\prime} \mathrm{S}, 42^{\circ} 52^{\prime} \mathrm{W}\right)$. Detailed information about climate of Maricá can be found in Mantovani \& Iglesias (2008). Considering their high frequency and wide distribution in the restinga of Maricá, Aechmea nudicaulis; Neoregelia cruenta e Vriesea neoglutinosa were chosen for this study. These three species occur in three different microhabitats: inside, outside, and at the border of vegetation islands.

Intact fruits were collected in the field, brought to the laboratory and seeds were separated and used after 1-2 days. In order to evaluate the effect of water stress on germinability, bromeliad seeds were abundantly watered with increasing concentrations of polyethyleneglicol 6000 (PEG 6000). Six solutions with water potentials of $\psi=-0.04,-0.14$, $-0.40,-0.90,-1.70$, and $-2.60 \mathrm{MPa}$ (Michael \& Kaufmann 1972) were used. Special care was taken in order to not induce hypoxia by flooding the seeds, which strongly limits bromeliad seed germination (Benzing 2000). Six closed $35 \mathrm{~mm}$ diameter Petri dishes, with ten seeds each, were prepared for each solution. Solutions were periodically changed along the 30 days of experiment in order to maintain its respective water potential. Another six dishes with only distilled water $(\psi=0.000)$ were the control. All dishes were kept at $27{ }^{\circ} \mathrm{C}$ air temperature and exposed to $3.5 \mu \mathrm{molm}^{-2} \mathrm{~s}^{-1}$ of PAR (Mantovani \& Iglesias 2008). Dishes were observed daily, and the onset of germination was detected by radicle extrusion (Mantovani \& Iglesias 2005).

Measurements and statistics of the germination process followed Ranal \& Santana (2006). Germination curves were calculated as daily cumulative percentage germination. For each species and treatment, the average germination time $(\bar{t})$, average germination rate $(v)$, synchronization index $(\bar{E})$ and number of daily events of germination were determined. Germinability was determined for the same experiment as the final percentage germinations of each treatment after 30 days and was taken from Mantovani \& Iglesias (2008). Mean germination time was calculated as the weighted mean of the germination time, using the number of seeds germinated at daily interval as weight, through the formula $\bar{t}=\sum_{\mathrm{i}=1}^{\mathrm{k}} \mathrm{n}_{\mathrm{i}} \mathrm{t}_{\mathrm{i}} / \sum_{\mathrm{i}=1}^{\mathrm{k}} \mathrm{n}_{\mathrm{i}}$, where $t_{i}$ : time from the start of the experiment to the $i^{\text {th }}$ day of observation; $\mathrm{n}_{\mathrm{i}}$ : number of seeds germinated in the day $i$ (not the accumulated number) and $k$ : last time of germination. Mean germination rate was determined as the reciprocal of the germination time, $v=1 / \bar{t}$, where $\bar{t}$ is the mean germination time. The synchronization index was calculated by the formula $\bar{E}=\sum_{\mathrm{i}=1}^{\mathrm{k}} f_{\mathrm{i}} \log _{2} f_{\mathrm{i}}$, being $f_{\mathrm{i}}=n_{\mathrm{i}} / \sum_{\mathrm{i}=1}^{\mathrm{k}} n_{\mathrm{i}}$, where $f_{\mathrm{i}}$ : relative frequency of germination, $n_{\mathrm{i}}$ : number of seeds germinated on the day $i$, and $k$ : last day of observation. For the number of daily events, it was considered an event each day with germination $\geq 1$ seed.

Average germination time and rate, synchonization index and number of germination events were compared per species. Data were first tested for parametric distribution using Kolmogorov-Smirnoff test, followed by the Bartlett test to verify homocedasticity. Parametric and homocedastic data were compared using ANOVA and Tukey. If data failed to present normal distribution, data transformations were applied. Data in percentage (germinability) and number (germination rate) were arcsen and square root transformed, respectively. If transformations were not successful, the existence of difference between non-parametric values was evaluated with Kruskal-Wallis (Zar 1996). In all analyses, a $5 \%$ level of probability was used (Ranal \& Santana 2006).

\section{Results}

Bromeliad seed germination was affected by the water stress. Germination only occurred under $\psi=0.00$ (control with distilled water), -0.04 , and $-0.14 \mathrm{MPa}$. No seeds germinated under water potentials lower than $-0.14 \mathrm{MPa}$ (data not shown). At the osmotic levels where germination occurred, the increase in water stress conditions induced variations not only in the germinability but also in the mean germination time, rate, and synchrony.

In water only, seeds of $A$. nudicaulis began to germinate after three days (figure 1 ). By the $6^{\text {th }}$ day germinability had reached the maximum level of $98 \%$ (table 1). Germination under -0.04 MPa also began on the $3^{\text {rd }}$ day, and reached a maximum of $83 \%$ by the $8^{\text {th }}$ day. Initial germination under - $0.14 \mathrm{MPa}$ was delayed until the $4^{\text {th }}$ day and reached a maximum of $65 \%$ by the $8^{\text {th }}$ day. Water stress increased the mean germination time of A. nudicaulis in 1 day, reducing rate from 0.23 to 0.18 days $^{-1}$. However the osmotic treatments did not induce significant statistical variations in the synchronicity values or number of daily germination events for this species. 
Table 1. Seed germination of bromeliad species Aechmea nudicaulis, Neoregelia cruenta and Vriesea neoglutinosa under water stress. $(\mathrm{G}=$ germinability*; $\bar{t}=$ mean germination time; $v=$ mean germination rate; $\bar{E}=$ synchronicity index; $N=$ number of daily germination events). Distinct letters represent significative differences per species at $P<0.05$. Data are mean \pm standard deviation ( $n=6$ dishes, 10 seeds per dish).

\begin{tabular}{llccccc}
\hline & $\begin{array}{l}\text { Germinating } \\
\text { conditions }\end{array}$ & $\begin{array}{c}\mathrm{G} \\
(\%)^{*}\end{array}$ & $\begin{array}{c}\bar{v} \\
(\text { days })\end{array}$ & $\begin{array}{c}v \\
\left(\text { days }^{-1}\right)\end{array}$ & $\begin{array}{c}\bar{E} \\
\text { (bits) }\end{array}$ & $\begin{array}{c}N \\
\text { (unitless) }\end{array}$ \\
\hline A. nudicaulis & Distilled water & $98.3 \pm 4.0^{\mathrm{a}}$ & $4.3 \pm 0.3^{\mathrm{a}}$ & $0.23 \pm 0.01^{\mathrm{a}}$ & $1.66 \pm 0,18^{\mathrm{a}}$ & $3.66 \pm 0.51^{\mathrm{a}}$ \\
& $-0.04 \mathrm{MPa}$ & $82.9 \pm 8.3^{\mathrm{b}}$ & $5.3 \pm 0.3^{\mathrm{b}}$ & $0.18 \pm 0.01^{\mathrm{b}}$ & $1.56 \pm 0,57^{\mathrm{a}}$ & $3.83 \pm 1.16^{\mathrm{a}}$ \\
& $-0.14 \mathrm{MPa}$ & $65.0 \pm 20.7^{\mathrm{b}}$ & $5.9 \pm 0.5^{\mathrm{c}}$ & $0.16 \pm 0.01^{\mathrm{b}}$ & $1.26 \pm 0.31^{\mathrm{a}}$ & $3.5 \pm 1.04^{\mathrm{a}}$ \\
V. neoglutinosa & Distilled water & $98.0 \pm 4.4^{\mathrm{a}}$ & $3.1 \pm 0.08^{\mathrm{a}}$ & $0.31 \pm 0,01^{\mathrm{a}}$ & $0.67 \pm 0.17^{\mathrm{a}}$ & $2.00^{\mathrm{a}}$ \\
& $-0.04 \mathrm{MPa}$ & $82.0 \pm 13.0^{\mathrm{b}}$ & $3.5 \pm 0.3^{\mathrm{a}, \mathrm{b}}$ & $0.28 \pm 0.03^{\mathrm{a}}$ & $1.16 \pm 0.6^{\mathrm{b}}$ & $2.6 \pm 0,89^{\mathrm{a}, \mathrm{b}}$ \\
& $-0.14 \mathrm{MPa}$ & $82.0 \pm 14.0^{\mathrm{b}}$ & $4.1 \pm 0.2^{\mathrm{b}}$ & $0.24 \pm 0.01^{\mathrm{b}}$ & $1.51 \pm 0.12^{\mathrm{b}}$ & $3.4 \pm 0,54^{\mathrm{b}}$ \\
& Distilled water & $100.0^{\mathrm{a}}$ & $3.5 \pm 0.1^{\mathrm{a}}$ & $0.27 \pm 0.01^{\mathrm{a}}$ & $1.13 \pm 0.19^{\mathrm{a}}$ & $2.33 \pm 0.51^{\mathrm{a}}$ \\
& $-0.04 \mathrm{MPa}$ & $83.0 \pm 14.3^{\mathrm{b}}$ & $5.1 \pm 0.3^{\mathrm{b}}$ & $0.19 \pm 0.01^{\mathrm{b}}$ & $2.03 \pm 0.26^{\mathrm{b}}$ & $4.66 \pm 0,81^{\mathrm{b}}$ \\
& $-0.14 \mathrm{MPa}$ & $79.3 \pm 11.6^{\mathrm{b}}$ & $4.5 \pm 0.5^{\mathrm{b}}$ & $0.22 \pm 0.03^{\mathrm{b}}$ & $1.71 \pm 0.34^{\mathrm{b}}$ & $3.83 \pm 0.98^{\mathrm{b}}$ \\
\hline
\end{tabular}

* = data from Mantovani \& Iglesias (2008) for the same experiment.
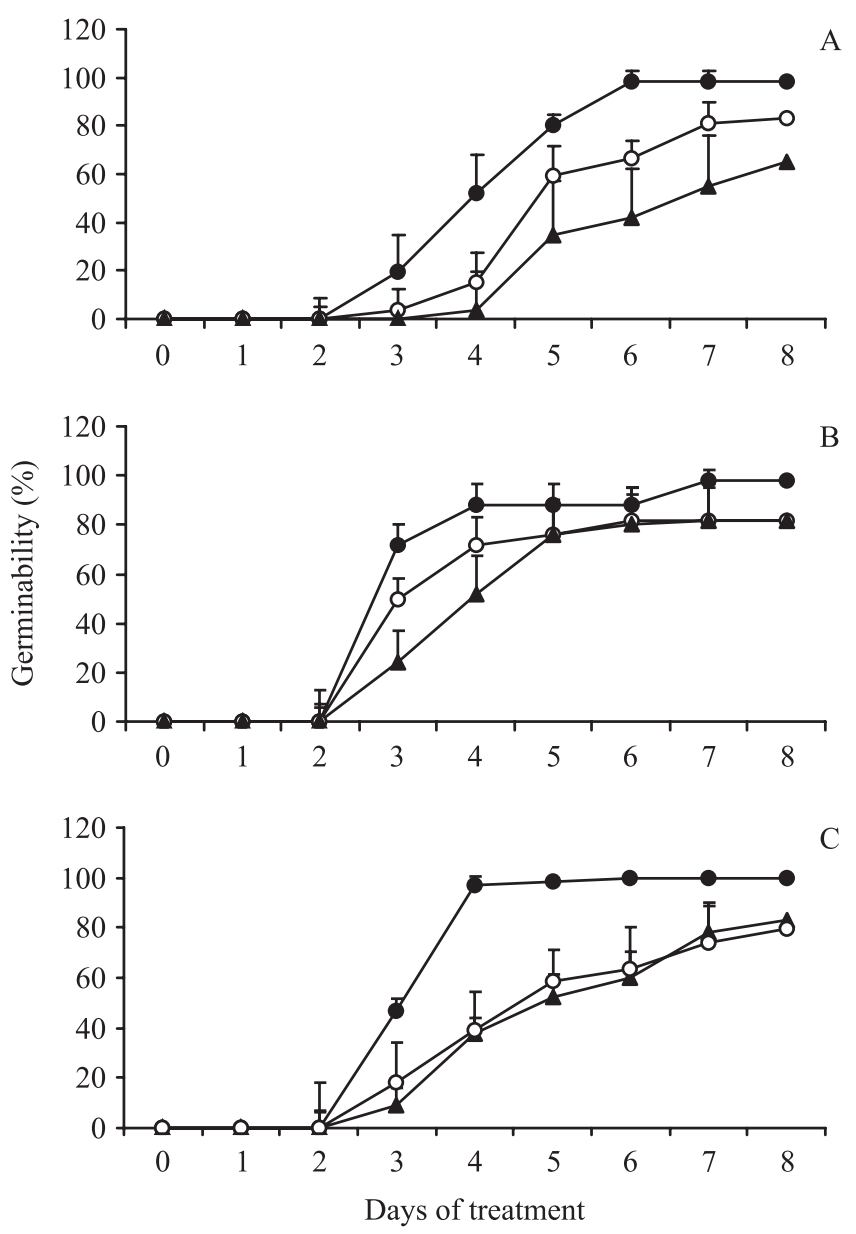

Figure 1. Percentage germination curves from seeds of Aechmea nudicaulis (A), Vriesea neoglutinosa (B) and Neoregelia cruenta (C) at different water potentials. Data are deviation mean \pm standard deviation $(n=6)$. Symbols are water $(\bullet),-0.04 \mathrm{MPa}(\mathrm{O})$ and $-0.14 \mathrm{MPa}(\boldsymbol{\Delta})$.
Germinability of $V$. neoglutinosa seeds was significantly higher for the control in comparison to the osmotic treatments. For the irrigation with water $(0.0 \mathrm{MPa})$, $-0.04 \mathrm{MPa}$ and $-0.14 \mathrm{MPa}$ solutions, germination began at the $3^{\text {rd }}$ day and reached a maximum of $98 \% ; 82 \%$ and $82 \%$ respectively, between the $6^{\text {th }}$ and $7^{\text {th }}$ day (table 1 ). Mean germination time also increased 1 day with osmotic treatments, decreasing significantly the germination rate at lower water potentials. Synchronicity index was also significantly higher under osmotic treatments. While germination at control conditions occurred along two days, under lower water potentials it occurred along 3.4 days.

Germination of $N$. cruenta seeds began on the $3^{\text {rd }}$ day (figure 1). By the $4^{\text {th }}$ day, seeds irrigated with water already achieved $100 \%$ germination, while seeds under $-0.04 \mathrm{MPa}$ and $-0.14 \mathrm{MPa}$ reached the maximum percentage of $83 \%$ and $79 \%$ respectively only at the $8^{\text {th }}$ day. Osmotic treatments increased mean germination time for $N$. cruenta seeds, delaying its germination rate. Lower values of synchronicity occurred under control conditions in comparison to the osmotic treatments. The number of daily germination events also increased for this species from 2.3 days under control conditions to 3.8 under lower water potentials.

\section{Discussion}

Seed germination of the terrestrial bromeliads $A$. nudicaulis, $V$. neoglutinosa and $N$. cruenta was affected by the water stress induced by PEG. Germination percentage (Mantovani \& Iglesias 2008), time, rate and 
synchronicity varied with increasingly negative water potentials from 0.0 to $-0.14 \mathrm{MPa}$. Data available in the literature for other plant families report seed germination using PEG solutions occurring from -0.5 to $-1.5 \mathrm{MPa}$ (Baskin \& Baskin 1998; Sy et al. 2001). The absence of bromeliad seed germination at water potentials lower than -0.14 MPa (Mantovani \& Iglesias 2008) indicates a constant and/or high moisture requirement for bromeliad seeds to germinate.

Other experimental data not using PEG also suggest a constant and/or high moisture requirement for germination of bromeliad seeds (Winkler et al. 2005). Benzing (2000) reports that after 14 weeks of a dry-wet cycle, seed germination of the epiphytic Tillandsia paucifolia Schlecht. on bark surfaces decreased from 30 to $7 \%$ when misting regimes ( $30 \mathrm{~min}$ of mist) varied from daily to once every six days. However, under high moisture conditions ( $4 \mathrm{~h}$ mist daily) germination after 4 weeks was higher (85-90\%). Castro-Hernandez et al. (1999) showed that germination of Tillandsia species with constant humidity is faster (until seven weeks) than under bark conditions at field (until 32 weeks). Winkler et al. (2005) state that time to seed germination was shorter for epiphytic Tillandsia species in less exposed canopy positions.

Despite the above evidences of a high water requirement of bromeliad seeds to germinate, we could not find any experimental report testing this hypothesis besides Pompelli et al. (2006) using solutions with increasing salt concentrations. For the same experiment and species analyzed here Mantovani \& Iglesias (2008) previously published final percentage germination results using solutions with increasing PEG concentrations. Both report water stress as a limiting factor for bromeliad seeds germination.

A high moisture requirement precludes seed germination under water stress conditions induced by transient or low water availability. Soil water availability depends on the balance between rainfall dynamics and soil water holding capacity (Schütz et al. 2002). In the restinga of Maricá, most rain falls in unpredictable events (Mantovani \& Iglesias 2008) probably not sufficient to maintain the water content of the sandy soil in the critical value that promotes germination (Sy et al. 2001). In dry-wet cycle experiment with the studied species (soil moisture varying daily from 0 (dry) to $100 \%$ (field capacity)), germination was about $24 \%$ and occurred after 12 to 19 consecutive days of watering with $125 \mathrm{mg}$ of water [g dw soil] ${ }^{-1}$ (Mantovani \& Iglesias 2008). With a continuous water supply, germinability of the same species surpassed $90 \%$ in three days (Mantovani \&
Iglesias 2008). Even during the summer rainy season, the mean soil water content of the sandy restinga soil (from 0.9 to $40.6 \mathrm{mg}$ of water [ $\mathrm{g} \mathrm{dw} \mathrm{soil}]^{-1}$ ) is often much lower than the necessary for germination under the dry-wet cycle experiment cited above (Mantovani \& Iglesias 2001). Moreover, only once during 1993-2000, did rain fell for 10 days consecutively. These data suggest that water availability in the field is most often below that necessary for germination under experimental conditions. Spreading seed germination along several events in unpredictable environments like restinga is important to maintain seeds along transitory periods, improving the seedling establishment as they could germinate and grow under ideal conditions (Pompelli et al. 2006, Vieira et al. 2007).

Time and rate of germination measure the speed of the germination process while the synchronicity index $(\bar{E})$ measures the degree of spreading of germination through time (Ranal \& Santana 2006). The lower rate and higher synchronicity values found for the bromeliad seeds show a tendency of a slower germination with polimodal distribution of the germination induced by the water stress. However the absence of terrestrial bromeliad seedlings in restinga suggests that ideal conditions for bromeliad seeds to germinate and/or seedlings to establish are rarely found under field conditions.

Bromeliads in restingas present terrestrial forms of the typical epiphytes from the neighboring Atlantic rainforest (Mantovani \& Iglesias 2005). A high bromeliad seedling mortality under canopy condition is a well known phenomenon (Benzing 2000) that stimulates the hypothesis that niche separation of bromeliads in canopies could be related to interspecific seedling susceptibility to stressful conditions. However Zotz \& Vollrath (2002) report that differences in vertical distribution of epiphytic bromeliads could not be explained by interspecific differences in site-specific survival at first-year seedling stage. They suggest that spatial distribution patterns are determined even earlier, probably resulting from species differences in seed dispersal or during germination.

We suggest that the phenomenon of germination influencing plant distribution, cited above for epiphytic bromeliads, could be occurring in restinga: water stress during seed germination limits the establishment and distribution of terrestrial bromeliads. These results reinforce the conclusion of Mantovani \& Iglesias (2008) that bromeliads are not able to act as pioneer plants germinating outside the vegetation islands of the restinga of Maricá. 
Acknowledgements - The authors are very grateful to Drs. Carol and Jerry Baskin and Mr. Dutch Vandervort for valuable help with the manuscript revision. The first author was sponsored by Capes.

\section{References}

BASKIN, C.C. \& BASKIN, J.M. 1998. Seeds: ecology, biogeography, and evolution of dormancy and germination. Academic Press, San Diego.

BENZING, D.H. 2000. Bromeliaceae: profile of an adaptive radiation. Cambridge University Press, Cambridge.

CASTRO-HERNANDEZ, J.C., WOLF, J.H.D., GARCIAFRANCO, J.G. \& GONZÁLEZ-ESPINOSA, M. 1999. The influence of humidity, nutrients and light establishment of the epiphytic bromeliad Tillandsia guatemalensis in the highlands of Chiapas, Mexico. Revista de Biologia Tropical 47:763-773.

MANTOVANI, A. \& IGLESIAS, R.R. 2001. Bromélias terrestres na restinga de Barra de Maricá, RJ: influência sobre o microclima, o solo, e a estocagem de nutrientes em ambientes de borda de moitas. Leandra 16:17-37.

MANTOVANI, A. \& IGLESIAS, R.R. 2005. Quando aparece a primeira escama? Estudo comparativo sobre o surgimento de escamas de absorção em três espécies de bromélias terrestres de restinga. Rodriguésia 56: 73-84.

MANTOVANI, A. \& IGLESIAS, R.R. 2008. Factors limiting seed germination of terrestrial bromeliads in the sandy coastal plains (restinga) of Maricá, Rio de Janeiro, Brazil. Rodriguésia 59:135-150.

MICHAEL, B.E. \& KAUFMAN, M.R. 1972. The osmotic potential of Polyethylene Glycol 6000. Plant Physiology 51:914-916.
PINHEIRO, F. \& BORGHETTI, F. 2003. Light and temperature requirements for germination of seeds of Aechmea nudicaulis (L.) Griesebach and Streptocalyx floribundus (Martius ex Schultes f.) Mez(Bromeliaceae). Acta Botanica Brasilica 17:27-35.

POMPELLI, M.F., FERNANDES, D. \& GUERRA, M.P. 2006. Germination of Dyckia encholirioides (Gaudichaud) Mez var. encholirioides under saline conditions. Seed Science \& Technology 34:759-763.

RANAL, M.A. \& SANTANA, D.G. 2006. How and why to measure the germination process? Revista Brasileira de Botânica 29:1-11.

SCHÜTZ, W., MILBERG, P. \& LAMONT, B.B. 2002. Germination requirements and seedling responses to water availability and soil type in four eucalypt species. Acta Oecologica 23:23-30.

SILVA, J.G. \& OLIVEIRA, A.S. 1989. A vegetação de restinga no Município de Maricá, RJ. Acta Botanica Brasilica 3:253-272.

SY, A., GROUZIS, M. \& DANTHU, P. 2001. Seed germination of seven Sahelian legume species. Journal of Arid Environments 49:875-882.

VIEIRA, D.C.M., SOCOLOWISKI, F. \& TAKAKI, M. 2007. Germinação de sementes de Dyckia tuberosa (Vell) Beer (Bromeliaceae) sob diferentes temperaturas em luz e escuro. Revista Brasileira de Botânica 30: $183-188$.

WINKLER, M., HÜLBER, K. \& HIETZ, P. 2005. Effect of canopy position on germination and seedling survival of epiphytic bromeliads in a mexican humid montane forest. Annals of Botany 95:1039-1047.

ZAR, J.H. 1996. Biostatistical analysis. Prentice Hall, New Jersey.

ZOTZ, G. \& VOLLRATH, B. 2002. Substrate preferences of epiphytic bromeliads: an experimental approach. Acta Oecologia 23:99-102. 
